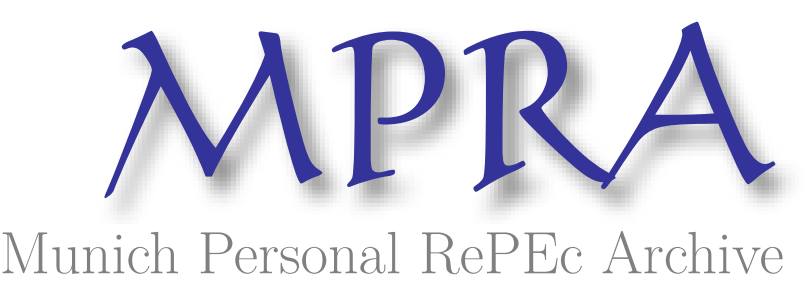

\title{
The Rise of Dollar Credit in Emerging Market Economies and US Monetary Policy
}

\author{
Huang, Anni and Kishor, N. Kundan \\ University of Wisconsin-Milwaukee, University of \\ Wisconsin-Milwaukee
}

1 May 2017

Online at https://mpra.ub.uni-muenchen.de/83474/

MPRA Paper No. 83474, posted 28 Dec 2017 07:23 UTC 


\title{
The Rise of Dollar Credit in Emerging Market Economies and US Monetary Policy
}

\author{
Anni Huang* $\quad$ N. Kundan Kishor ${ }^{\dagger}$
}

\begin{abstract}
This paper examines the hypothesis that the boom in dollar credit in the emerging market economies is associated with excessively low interest rate in the US. For this purpose, we use a multivariate correlated unobserved component model that allows for correlation between shocks to dollar credit, interest rates and dollar index both in the short-run and in the long-run. In addition, it also provides us a quantitative estimate of the permanent and transitory movements in dollar credit in emerging markets, US interest rate and the dollar index. The results from this model do suggest that a temporary decline in interest rate and dollar index below their long-run levels are associated with an increase in dollar credit with a very high degree of negative correlation. The estimate of the cyclical component of the dollar credit in emerging market from our model captures the recent boom and bust in this market and compares favorably to a univariate trend-cycle decomposition benchmark.
\end{abstract}

Keywords: Dollar Credit, Emerging Market Economies, Monetary Policy Spillover, Trend-Cycle Decomposition, State-Space Model, Kalman Filter JEL classification: E32, E51, E58, F32, F34, F36, G15

*Department of Economics, University of Wisconsin-Milwaukee, PO Box 413, Bolton 831, Milwaukee, WI 53211, USA. E-mail: huanga@uwm.edu.

$\dagger$ Department of Economics, University of Wisconsin-Milwaukee, PO Box 413, Bolton 822, Milwaukee, WI 53211, USA. E-mail: kishor@uwm.edu. 


\section{Introduction}

The surge of dollar credit in the emerging market economies (EMEs henceforth) has drawn close attention from the international financial market participants and the policymakers due to its potential role in the monetary and financial stability of the global economy. The data from the Bank of International Settlements (BIS) shows that the outstanding US dollar credit to non-bank borrowers in the EMEs has risen from 1.69 trillion dollar in 2008Q4 to 3.25 trillion dollar in 2015Q4. The cyclical nature of EME dollar credit $^{1}$ could also amplify the overall credit condition in the domestic economy and increase the vulnerability of these the EMEs in dealing with negative economic shocks. For example, during the expansionary phase, the dollar credit floods into the EMEs, which raises the challenge to stabilize the domestic monetary base. In the contractionary phase, the dramatic outflow of dollar credit also creates difficulty to stabilize the exchange rate and asset prices (Avdjiev et al., 2012). This was very evident during the 'taper tantrum' of 2013. On the other hand, however, it has also been argued that the increasing role of dollar credit in the EMEs may signify a more integrated global financial market and a greater degree of risk sharing across different countries.

The growing academic interest in the literature on examining the dollar credit in the EMEs has also coincided with the recent emphasis on the role of US monetary policy in boosting global liquidity. Global liquidity refers to the global factor that drives cross-border spillover in financial conditions and credit growth. Shin (2013) proposes two phases of global liquidity after the Millennium. The first phase of global liquidity transmission (2002-2008) is more associated in form of bank loans through global banking system. The international bond market gradually took over the share of bank loans in the second phase of global liquidity transmission starting in 2009. Since then, the large

\footnotetext{
${ }^{1}$ EME dollar credit in this paper refers to the outstanding dollar credit to non-bank borrowers in emerging market economies. It is composed of credit extended by all lenders: banks and non-bank creditors, from foreign and domestic sources. Specifically, it is composed of loans extended by banks and purchases of debt securities by both banks and by non-banks (as proxied by issues of debt securities). Based on the guide to use BIS global liquidity indicators, emerging market economies refers to the countries including Argentina, Brazil, Chile, China, the Czech Republic, Hong Kong, Hungary, India, Indonesia, Korea, Poland, Russia, South Africa, Thailand, Turkey, Malaysia, Mexico, Saudi Arabia, and Singapore.
} 
scale of bond purchases as a result of of Quantitative Easing (QE) programs had led to the portfolio re-balancing effect ${ }^{2}$ in the international bond market. A few papers and policy studies have provided narrative evidence (Borio, et al. 2011; McCauley, et al., 2015 ) in support of the hypothesis that the abundance of global liquidity was one of the causes of the boom of the dollar credit in the EMEs.

Although much attention has been given to the rise of dollar credit and its apparent relationship with US monetary policy and the valuation of the US dollar, not much work has been done to systematically disentangle the short-run and the long-run relationships among these variables. It is perfectly plausible to think that the short-run relationship between dollar credit in emerging markets and the stance of monetary policy in the US may be very different from its long-run relationship. The long-run dollar credit in the emerging market may be driven more by its long-run absorptive capacity instead of the short-run increase in liquidity or the weakness of the US dollar. Therefore, it is very important to decompose the overall EME dollar credit and isolate the cyclical variations from its long-term trend, by taking into account the information on US interest rate and the dollar valuation. In addition to estimating the short-run and the long-run correlation between the shocks to each series, this approach will also yield us a quantitative estimate of how big the cyclical component in dollar credit was at different points in time during the last few years.

To examine the long-run and short-run relationship among these variables, we propose to use a correlated multivariate unobserved component (UC hereafter) model which is a multivariate counterpart of the correlated univariate UC model as outlined in Morley, Nelson and Zivot (2003). ${ }^{3}$ This model allows us to decompose the movements in dollar credit, interest rate and dollar index ${ }^{4}$ into a slow-moving trend component and a cyclical component simultaneously. The slow-moving trend captures the long-run evolution of

\footnotetext{
${ }^{2}$ The portfolio re-balancing effect in this context means when the Fed purchases bonds from the investors, the investors need to purchase additional bonds from somewhere else, for instance, emerging market economies, if they want to maintain the original weights on different asset classes.

${ }^{3}$ Multivariate correlated unobserved component model has also been applied in other context. See for example, Sinclair (2009), Morley (2007), Bhatt and Kishor (2016) among others.

${ }^{4}$ Dollar index refers to the broad trade-weighted US dollar index. This variable is a proxy of the dollar valuation against other currencies.
} 
these variables and the cyclical component captures the short-run movements. This model allows us to not only estimate the permanent and transitory movements, but also provides us a measure of correlation of the long-run movements and the short-run movements among dollar credit, interest rate and dollar index. ${ }^{5}$ For example, if the recent narrative about the role of exceptionally low interest rate in boosting EME dollar credit is correct, then we would observe a negative correlation between the shock to the transitory component of dollar credit and the shock to transitory component of the US interest rate. To take into account the zero lower bound problem associated with the federal funds rate and the short-term interest rate in the recent time period, we use the shadow interest rate as proposed by $\mathrm{Wu}$ and Xia (2016) as a proxy for US monetary policy stance. The shadow interest rate takes into account the impact of unconventional monetary policy on interest rate and unlike the federal funds rate, is allowed to fall below zero.

To understand the intuition behind the structure of our model, one could think of the credit activities in the EMEs as a form of international investment. From the investors' perspective, the return of lending dollar in the EMEs depends on the interest rate paid from these credit instruments. The US interest rate, the risk-free rate in the international credit market, is a major factor in pricing the interest rates on the international bank loans and the corporate bond yields. From the EME borrowers' perspective, the dollar valuation in the currency market is also critical in determining their real external debt burden, besides the US monetary policy rate. The expectation of domestic currency appreciation will lower the expected external debt burden in the future and vice versa. To summarize, we can think of this three-variable dynamic system as the application of interest rate parity in international credit activities.

We find interesting and economically meaningful results from the estimated multivariate correlated unobserved component model. The maximum likelihood estimates of our correlated multivariate UC model suggest that there is a strong negative correlation between the transitory shock to dollar credit and the transitory shock to the US interest

\footnotetext{
${ }^{5}$ It should be noted at the outset that we are interested in understanding the role of external forces in dollar credit growth. Domestic factors like GDP growth may also affect the movements in dollar credit growth in the EMEs. In our set up, the dynamic behavior of trend and cycle should be able to capture some of these effects.
} 
rates. This suggests that a temporary decline in interest rate below its long-run level is associated with an increase in dollar credit above its long-run level. We also find a very high negative correlation between the transitory shocks to dollar credit and the transitory shocks to the dollar index, implying an appreciation of US dollar is associated with a decline in dollar credit in the EMEs in the short-run. These results support the anecdotal and narrative evidence on the strong relationship between dollar credit and the US interest rates and also between dollar credit and the strength of the US dollar. We also find that the trend-cycle decomposition of EME dollar credit from our multivariate correlated unobserved component model captures the recent boom and bust behavior and compares favorably to a univariate trend-cycle decomposition benchmark. In particular, our results suggest that the dollar credit before the taper tantrum was $10 \%$ above its long-run trend in the emerging market economies.

The rest of the paper is structured as follows. The second section provides a literature review about global liquidity transmission and discusses the associated monetary policy spillover effect. The third section introduces the data used in this study and the setup of the correlated multivariate UC model. The fourth section interprets and presents the results from the model. The last section concludes the paper.

\section{Literature Review}

The literature on dollar credit in the EMEs is nascent. Few papers have tried to address this issue from different perspectives. In understanding the phenomenon that dollar credit outside the US behaves differently from the US domestic dollar credit, Borio, McCauley and McGuire (2011) take a look at the recent behavior of international credit and associate it with the overall credit conditions. Their descriptive analysis reveals the fact that US dollar credit in some countries has been outgrowing the overall credit during the credit booms. A formal analysis later on from Avdjiev, McCauley and McGuire (2012) regresses the cross-sectional change in credit-to-GDP ratio on the change in international credit during the credit boom phase (2002-2008) and regresses the credit growth in the 
EMEs on the change in international credit during the credit bust phase (2008-2011). Their results suggest that international credit amplifies the overall credit cycles in the EMEs. While in these studies, the authors often use the share of international credit in the overall credit to measure the cyclical variation of international credit, it is worthwhile to recognize that the trend of international credit and the trend of the overall credit can be driven by different underlying factors, therefore they do not need to share the common trend in the numerator and denominator. For instance, the long-term trend of international credit could be explained by the integration of international financial market, but the long-term trend of the overall credit condition may respond more to the domestic economic fundamentals. Thus without isolating the long-term trend from these two credit series, it is very difficult to perform a clean analysis about the cyclical comovement between the international credit and the overall credit condition.

Since the recent global financial crisis of 2008-2009, the outstanding US dollar credit to the non-bank borrowers in the EMEs has roughly doubled within the past seven years. The commentators associate this surge to US monetary policy spillover, mainly because of the ultra low interest rates in the US. He and McCauley (2013) survey a number of studies on the transmission of monetary policy of the major advanced economies to East Asia and conclude that policy rates, bond yields and exchange rates are three price channels in the transmission process. McCauley, McGuire and Suchko (2015) also link the US monetary policy, leverage and flow into bond funds to explain the dollar credit extended to non-US borrowers. In this paper, since our goal is to understand the behavior of the overall dollar credit condition, regardless of the credit instruments, we focus on the two price channels - interest rate and currency appreciation/depreciation, an analytical framework which can be interpreted as based upon international interest rate parity theory. ${ }^{6}$

It should be pointed out that we focus on EME dollar credit, a subject we believe to be ideal to study the monetary policy spillover effect in global liquidity transmission. This is because, the composition of bank loan and bond issuance depends on country-specific contexts, for instance, the regulatory emphasis of capital control. Tighter regulation on

\footnotetext{
${ }^{6}$ See the empirical model section for details.
} 
international banking practice could push the domestic borrowers to issue bonds overseas and vice versa (Caballero et al., 2015). Since our goal is to understand the trend and cycle of the dollar credit in emerging market economies, we purposely ignore the credit breakdown based on types of financial instruments. Furthermore, we choose to study EME dollar credit, instead of Euro, Yen or other currency credit, is because different currency credit could be sensitive to different monetary policy rates and dollar credit dominates other currencies in the currency breakdown of international credit (Borio, et al., 2011). The last but not the least, we work with the dollar credit in the EMEs, because the dollar credit outside US may respond to factors in different ways when it comes to the EMEs compared to other advanced economies. (Borio, et al. 2011; McCauley, et al., 2015)

\section{$3 \quad$ Data and Empirical Model}

\subsection{Data Description}

Our sample period spans from the first quarter of 2000 to the last quarter of 2015. The sample period is based on data availability. Measuring dollar credit can be a challenging exercise. Fortunately, the Bank of International Settlements (BIS) website provides global liquidity indicators to measure the ease of financing in global financial markets. ${ }^{7}$ Among various global credit aggregates, we use the US dollar credit to non-bank sector in the EMEs in this study. This measure aggregates all the maturities of credit instruments. The original data is measured in trillions of US dollar and we take the natural log of this series and use the log-transformed series in the model estimation.

The second variable in our exercise is US interest rate that proxies the stance of US monetary policy. The ideal candidate would have been the federal funds rate if there was not a zero lower bound (ZLB) problem. The ZLB issue arises during and after the Great Recession, as the Fed quickly lowered the federal funds rate close to zero and

\footnotetext{
${ }^{7}$ The term global liquidity is used by the BIS to mean the ease of financing in global financial markets. BIS publishes measures of global liquidity indicators. See https : //www.bis.org/statistics/gli.htm?m for details.
} 
also implemented the unconventional monetary policies, including large-scale purchases of financial assets from private financial corporations. These unconventional monetary policies helped inject more liquidity into the market than implied by the federal funds rate, which basically had no room to be lowered further. The overall monetary policy stance thus can not simply be captured by the variations in the federal funds rate itself.

To take this ZLB problem into account, Wu and Xia (2016) proposed to use the shadow interest rate to provide a comprehensive measure to summarize the overall stance of monetary policy while the federal funds rate stuck at the ZLB environment. The shadow interest rate measure originated from the idea in Black (1995) to price the interest rate as an option. Wu and Xia (2016) conducted an analytical approximation for the forward rate in the Shadow Rate Term Structure Model (SRTSM), by linearizing the state-space model representation of the three-factor SRTSM. Then they used the estimated parameters and decomposed three unobserved factors to compute the shadow interest rate. The likelihood ratio test could not reject the hypothesis that the parameters relating the shadow interest rate to key macroeconomic variables under the ZLB environment are the same as those that related the federal funds rate to those variables before the Great Recession. Because of its intuitive appeal, $\mathrm{Wu}$ and Xia (2016) shadow interest rate measure has been gaining widespread attention. ${ }^{8}$

Because of the above mentioned reasons, we use the shadow interest rate proposed by $\mathrm{Wu}$ and Xia (2016) as a proxy for the Fed's overall monetary policy stance. The reason we choose to use this measure in our benchmark estimation over some alternative measures, for instance, the longer-term interest rates which suffer less from the ZLB issue, is because the term premium in the long-term interest rates could potentially contaminate the monetary policy stance. Nevertheless, we still perform a robustness test with 1-year treasury bill rate, given the fact that our dollar credit measure aggregates all the credit instruments regardless of their term to maturity. The third variable in our exercise is the US dollar exchange rate in the global currency market. We use the broad trade-weighted US dollar index to measure the dollar valuation in the currency market. The larger the

\footnotetext{
${ }^{8}$ Federal Reserve Bank of Atlanta posts Wu and Xia shadow federal funds rate on the website: https : $/ /$ www.frbatlanta.org/cqer/research/shadow ${ }_{r}$ ate.aspx?panel $=1$
} 
index, the stronger the US dollar is, or equivalently, the more US dollar appreciates, and vice versa.

\subsection{Empirical Model}

In this paper, we use a trivariate unobserved component model to model the dynamics in EME dollar credit $\left(Y_{t}\right)$, interest rate $\left(I_{t}\right)$ and dollar index $\left(D_{t}\right)$. This model is multivariate extension of the model proposed by Morley, Nelson and Zivot (2003). To understand the intuition behind the structure of our model, one could think of the credit activities in the EMEs as a form of international investment. From the investors' perspective, the return of lending dollar in the EMEs depends on the interest rate paid from these credit instruments. The US monetary policy rate, the risk-free rate in the international credit market, is a major factor in pricing the interest rates on the international bank loans and the corporate bond yields. From the EME borrowers' perspective, the dollar valuation in the currency market is also critical in determining their real external debt burden, besides the US monetary policy rate. The expectation of domestic currency appreciation will lower the expected external debt burden in the future and vice versa. To summarize, we can think of this three-variable dynamic system as the application of interest rate parity in international credit activities. Moreover, the interest rate parity has to hold in both the short-run and the long-run market equilibrium. Therefore, the dynamics of interest rate and exchange rate will provide useful information in explaining the dynamics of dollar credit in the EMEs. ${ }^{9}$ Our model takes the following form:

\section{EME Dollar Credit:}

$$
\begin{gathered}
Y_{t}=\tau_{y t}+c_{y t} \\
\tau_{y t}=\mu_{y}+\tau_{y t-1}+\eta_{y t}, \eta_{y t} \sim i i d N\left(0, \sigma_{\eta y}^{2}\right) \\
c_{y t}=\phi_{1 y} c_{y t-1}+\phi_{2 y} c_{y t-2}+\varepsilon_{y t}, \varepsilon_{y t} \sim i i d N\left(0, \sigma_{\varepsilon y}^{2}\right)
\end{gathered}
$$

\footnotetext{
${ }^{9}$ It can be argued that a more realistic model should also include more variables. This is a valid criticism. However, the objective of this paper is to understand the dynamic relationship between US monetary policy and dollar credit in the EMEs, therefore, in the interest of parsimony we focus on these three variables.
} 


\section{Interest Rate:}

$$
\begin{gathered}
I_{t}=\tau_{i t}+c_{i t} \\
\tau_{i t}=\mu_{i}+\tau_{i t-1}+\eta_{i t}, \eta_{i t} \sim i i d N\left(0, \sigma_{\eta i}^{2}\right) \\
c_{i t}=\phi_{1 i} c_{i t-1}+\phi_{2 i} c_{i t-2}+\varepsilon_{i t}, \varepsilon_{i t} \sim \operatorname{iidN}\left(0, \sigma_{\varepsilon i}^{2}\right)
\end{gathered}
$$

\section{Dollar Index:}

$$
\begin{gathered}
D_{t}=\tau_{d t}+c_{d t} \\
\tau_{d t}=\mu_{d}+\tau_{d t-1}+\eta_{d t}, \eta_{d t} \sim i i d N\left(0, \sigma_{\eta d}^{2}\right) \\
c_{d t}=\phi_{1 d} c_{d t-1}+\phi_{2 d} c_{d t-2}+\varepsilon_{d t}, \varepsilon_{d t} \sim i i d N\left(0, \sigma_{\varepsilon d}^{2}\right)
\end{gathered}
$$

Each series is decomposed into a stochastic trend component $\left(\tau_{j t}, i=Y, \operatorname{Ior} D\right)$ and a cyclical component $\left(c_{j t}, i=Y\right.$, Ior $\left.D\right)$ implying an $\mathrm{I}(1)$ process for all the variables. The non-stationarity of these variables are confirmed by the unit root tests where we do not reject the null of unit root for all the variables. ${ }^{10}$ We also do not impose the common trend restriction, i.e., all three variables have their own trend and cycle components and these components are allowed to have a certain degree of correlation based on the economic intuition we will discuss later. In fact, we do test for cointegration among these three variables and do not find evidence to support this for the sample period under study.

Secondly, we specify the dynamics of trend and cycle components. The cyclical component in each series is assumed to follow an AR (2) process. This assumption captures the auto correlation structures as observed in the correlogram and provides rich dynamics in the data series to enable us to identify all the parameters under the state-space model framework (Morley, Nelson and Zivot, 2003). The trend components are assumed to follow a random walk process with a drift, and as mentioned above, we do not impose a common trend among these three variables. ${ }^{11}$

Thirdly, we assume the shocks to the trend and cycle components follow a white

\footnotetext{
${ }^{10}$ The detailed results are not reported here for brevity. They are available upon request.

${ }^{11}$ We also explore the random walk model with drift to capture the potential shocks in the percentage changes in additional to the shocks to the levels for stochastic trend. The results do not show evidence in support of this model..
} 
noise process, but allow for non-zero cross-correlation across series. The shocks to the trend components $\left(\eta_{j t}, i=Y, I\right.$, or $\left.D\right)$ have a long-run effect on the trend because the trend is assumed to follow a random walk process. The shocks to the cyclical component $\left(\varepsilon_{j t}, i=Y\right.$, Ior $\left.D\right)$ have a short-run effect on the cycle because the cycle follows a stationary autoregressive process with two lags. The shocks to each trend component are allowed to be correlated across each other, so are the shocks to the cyclical components. However, we impose the zero correlation between the shocks to the trend component and the shocks to the cycle component within and between series. That is to say, we assume that the shocks that generate a long-run effect are different from the shocks that generate a short-run effect. This assumption for example, isolates the monetary policy shocks, which often are considered neutral in the long term, from the productivity shocks, which has a persistent effect in the real economy.

Below is the correlated multivariate unobserved component model setup based on the previous discussion. It should be pointed out that, in the variance-covariance matrix of the shocks to the trend and cycle, $\sigma_{\eta y \eta i}, \sigma_{\eta y \eta d}$, and $\sigma_{\eta i \eta d}$ are the pairwise covariance of the shocks to the trend of EME dollar credit, monetary policy rate and dollar index. $\sigma_{\varepsilon y \varepsilon i}, \sigma_{\varepsilon y \varepsilon d}$, and $\sigma_{\varepsilon i \varepsilon d}$ are the pairwise covariance of the shocks to the cycle of EME dollar credit, monetary policy rate and dollar index. The estimates of correlation coefficients, instead of covariances, will be reported in Table 1 . We estimate the model using the classical maximum likelihood via the Kalman filter. ${ }^{12}$

\footnotetext{
${ }^{12}$ See Kim and Nelson (2000) for the details of the estimation procedure.
} 
Measurement Equation:

$$
\left[\begin{array}{c}
Y_{t} \\
I_{t} \\
D_{t}
\end{array}\right]=\left[\begin{array}{lllllllll}
1 & 1 & 0 & 0 & 0 & 0 & 0 & 0 & 0 \\
0 & 0 & 0 & 1 & 1 & 0 & 0 & 0 & 0 \\
0 & 0 & 0 & 0 & 0 & 0 & 1 & 1 & 0
\end{array}\right]\left[\begin{array}{c}
\tau_{y t} \\
c_{y t} \\
c_{y t-1} \\
\tau_{i t} \\
c_{i t} \\
c_{i t-1} \\
\tau_{d t} \\
c_{d t} \\
c_{d t-1}
\end{array}\right]
$$

Transition Equation:

$\left[\begin{array}{c}\tau_{y t} \\ c_{y t} \\ c_{y t-1} \\ \tau_{i t} \\ c_{i t} \\ c_{i t-1} \\ \tau_{d t} \\ c_{d t} \\ c_{d t-1}\end{array}\right]=\left[\begin{array}{c}\mu_{y} \\ 0 \\ 0 \\ \mu_{i} \\ 0 \\ 0 \\ \mu_{d} \\ 0 \\ 0\end{array}\right]+\left[\begin{array}{ccccccccc}1 & 0 & 0 & 0 & 0 & 0 & 0 & 0 & 0 \\ 0 & \phi_{1 y} & \phi_{2 y} & 0 & 0 & 0 & 0 & 0 & 0 \\ 0 & 1 & 0 & 0 & 0 & 0 & 0 & 0 & 0 \\ 0 & 0 & 0 & 1 & 0 & 0 & 0 & 0 & 0 \\ 0 & 0 & 0 & 0 & \phi_{1 i} & \phi_{2 i} & 0 & 0 & 0 \\ 0 & 0 & 0 & 0 & 1 & 0 & 0 & 0 & 0 \\ 0 & 0 & 0 & 0 & 0 & 0 & 1 & 0 & 0 \\ 0 & 0 & 0 & 0 & 0 & 0 & 0 & \phi_{1 d} & \phi_{2 d} \\ 0 & 0 & 0 & 0 & 0 & 0 & 0 & 1 & 0\end{array}\right]\left[\begin{array}{c}\tau_{y t-1} \\ c_{y t-1} \\ c_{y t-2} \\ \tau_{i t-1} \\ c_{i t-1} \\ c_{i t-2} \\ \tau_{d t-1} \\ c_{d t-1} \\ c_{d t-2}\end{array}\right]+\left[\begin{array}{c}\eta_{y t} \\ \varepsilon_{y t} \\ 0 \\ \eta_{i t} \\ \varepsilon_{i t} \\ 0 \\ \eta_{d t} \\ \varepsilon_{d t} \\ 0\end{array}\right]$ 
Variance-Covariance Matrix of the Shocks to Trend and Cycle:

$$
Q=\left[\begin{array}{ccccccccc}
\sigma_{\eta y}^{2} & 0 & 0 & \sigma_{\eta y \eta i} & 0 & 0 & \sigma_{\eta y \eta d} & 0 & 0 \\
0 & \sigma_{\varepsilon y}^{2} & 0 & 0 & \sigma_{\varepsilon y \varepsilon i} & 0 & 0 & \sigma_{\varepsilon y \varepsilon d} & 0 \\
0 & 0 & 0 & 0 & 0 & 0 & 0 & 0 & 0 \\
\sigma_{\eta y \eta i} & 0 & 0 & \sigma_{\eta i}^{2} & 0 & 0 & \sigma_{\eta i \eta d} & 0 & 0 \\
0 & \sigma_{\varepsilon y \varepsilon i} & 0 & 0 & \sigma_{\varepsilon i}^{2} & 0 & 0 & \sigma_{\varepsilon i \varepsilon d} & 0 \\
0 & 0 & 0 & 0 & 0 & 0 & 0 & 0 & 0 \\
\sigma_{\eta y \eta d} & 0 & 0 & \sigma_{\eta i \eta d} & 0 & 0 & \sigma_{\eta d}^{2} & 0 & 0 \\
0 & \sigma_{\varepsilon y \varepsilon d} & 0 & 0 & \sigma_{\varepsilon i \varepsilon d} & 0 & 0 & \sigma_{\varepsilon d}^{2} & 0 \\
0 & 0 & 0 & 0 & 0 & 0 & 0 & 0 & 0
\end{array}\right]
$$

\section{Results and Interpretation}

We present the results of this model in the next three subsections. In the first subsection, we discuss the parameter estimates and also provide interpretation for the correlation of the shocks to the trend and cycle among the three variables. In the second subsection, we discuss the evolution of the estimated trend and cycle of each series and examine whether the trend and cycle components capture the long-run trend and the cyclical variation during the sample period. In the third subsection, we look at both the long-term and short-term comovement among these three variables.

\subsection{Dynamic Relationship among EME dollar Credit, US In- terest Rate and the Dollar Index}

Table 1 provides the maximum likelihood estimates of all the parameters. The corresponding standard errors are in the parentheses. The results suggest that the cyclical shocks dominate the variation in the overall EME dollar credit. The standard deviation of the shocks in the trend of EME dollar credit is $0.014^{13}$, smaller compared to the stan-

\footnotetext{
${ }^{13}$ The unit of measurement here is $\log$ trillion of US dollars for the EME dollar credit series. The unit of measurement for US shadow interest rate is percentage point and the unit of measurement for dollar index is the log transformation of the original index.
} 
dard deviation of the shocks in the cycle, 0.017. Additionally, for the shadow interest rate, the standard deviation of the shocks in the trend is 0.274 , almost twice as large as the standard deviation of the shocks in the cycle. The results seem to suggest that variations in slow moving component in the shadow interest rate is dominant. However, the variations in cyclical component are also significant. For the dollar index, the standard deviation of shocks to the trend and cycle components are 0.015 and 0.016 respectively, implying similar importance of transitory and permanent variation in dollar index. As far as the estimated parameters of the cyclical components are concerned, we find that the cyclical component of all the variables are persistent implying a shock to the cycle, though transient, persists for a while.

The correlation analysis of the shocks to the cycles among these variables suggests that the cyclical variation among EME dollar credit, monetary policy rate and dollar credit are strongly correlated. The correlation coefficient between the transitory shock to dollar credit and the transitory shock to US interest rate is -0.97 . The correlation coefficient between the transitory shock to EME dollar credit and the transitory shock to dollar index is -0.94. And the correlation coefficient between the transitory shock to US interest rate and the the transitory shock to dollar index is 0.99. The standard errors of these estimated parameters confirm that these correlation coefficients are significantly different from zero.

The strong negative correlation between the transitory shock to US interest rate and the transitory shock to dollar credit in the EMEs suggests that, a temporary decrease in US interest rate below its long-run trend leads to a temporary increase in EME dollar credit as it lowers the cost of borrowing. In addition to the lower cost, the transitory decline in interest rate may also reflect temporary abundance of liquidity as witnessed during the QE programs. The negative correlation between transitory shock to dollar index and transitory shock to dollar credit in the EMEs is also very intuitive. An increase in dollar index implies an appreciation of dollar index above its long-run trend and these movements make the dollar financing activities in the EMEs less appealing temporarily.

We can motivate the strong positive correlation between the transitory shock to US 
interest rate and the transitory shock to US dollar index by considering an open economy's short-run equilibrium model. At the initial output level and given the sticky price level in the short-run, an increase in US money supply pushes down the US interest rate. Since the US monetary change is temporary and does not affect the expected future exchange rate, so to preserve interest rate parity, the exchange rate must depreciate immediately to create the expectation that the US dollar will appreciate in the future. Therefore, in the short run, a negative transitory shock to US monetary policy rate is predicted to associate with a negative transitory shock to US dollar index, which is exactly what we identify in our model estimation.

The correlation analysis of the shocks to the trends among these variables confirm our earlier finding that these three variables do not share a common trend and hence, are not cointegrated. ${ }^{14}$ The correlation coefficient between the permanent shocks to EME dollar credit and the permanent shocks to US interest rate is 0.67 . The correlation coefficient between the permanent shock to US interest rate and the permanent shocks to dollar index is -0.68 . The standard errors of these estimated parameters confirm that these correlation coefficients are significantly different from zero. The correlation coefficient between the permanent shock to EME dollar credit and the permanent shock to dollar index is insignificant and low. Therefore, it is not likely that these variables share the common trend, which supports the conjecture that we need to decompose the trend and cycle components from the series to understand the business cycles of these variables.

The negative correlation between the permanent shock to US interest rate and the permanent shock to dollar index seems puzzling at the first glance. However, it can be explained using the forward looking behavior of these variables. If an unexpected permanent increase in interest rate provide the signal that inflation is expected to go up in future, then nominal exchange rate may respond instantaneously in response to this news about higher than expected inflation. Similarly, the forward-looking behavior can explain the positive correlation between permanent shock to interest rate and permanent shock to dollar credit. An unexpected permanent increase in interest rate may provide

\footnotetext{
${ }^{14}$ In extreme case of cointegration, we will observe perfect correlation in the trend shock of these variables.
} 
Table 1: Maximum Likelihood Estimates: A Correlated Multivariate UC Model

This table reports the maximum likelihood estimates of all the parameters in the state-space model using the data from the whole sample period 2000-2015. The dollar credit in the EMEs is measured in log trillions of USD. The shadow interest rate is measured in percentage points. The US dollar index is in logs.

\begin{tabular}{|c|c|c|}
\hline Description & Parameter & $\begin{array}{c}\text { Estimate } \\
\text { (Standard Error) }\end{array}$ \\
\hline \multirow[t]{2}{*}{ Log likelihood value } & $l l v$ & 295.8723 \\
\hline & EME dollar credit & \\
\hline S.D. of permanent shocks to the EME dollar credit & $\sigma_{\eta y}$ & $\begin{array}{c}0.0139 \\
(0.0041)\end{array}$ \\
\hline S.D. of temporary shocks to the EME dollar credit & $\sigma_{\varepsilon y}$ & $\begin{array}{c}0.0168 \\
(0.0033)\end{array}$ \\
\hline the EME dollar credit drift & $\mu_{y}$ & $\begin{array}{c}0.0274 \\
(0.0025)\end{array}$ \\
\hline EME dollar credit 1st AR parameter & $\phi_{1 y}$ & $\begin{array}{l}1.3851 \\
(0.1399)\end{array}$ \\
\hline \multirow[t]{2}{*}{ EME dollar credit 2nd AR parameter } & $\phi_{2 y}$ & $\begin{array}{l}-0.4770 \\
(0.1251)\end{array}$ \\
\hline & shadow interest rate & \\
\hline S.D. of permanent shocks to shadow interest rate & $\sigma_{\eta i}$ & $\begin{array}{c}0.2738 \\
(0.0312)\end{array}$ \\
\hline S.D. of temporary shocks to shadow interest rate & $\sigma_{\varepsilon i}$ & $\begin{array}{c}0.1549 \\
(0.0327)\end{array}$ \\
\hline Shadow interest rate drift & $\mu_{i}$ & $\begin{array}{l}-0.0792 \\
(0.0481)\end{array}$ \\
\hline Shadow interest rate 1 st AR parameter & $\phi_{1 i}$ & $\begin{array}{c}1.9072 \\
(0.0355)\end{array}$ \\
\hline \multirow[t]{2}{*}{ Shadow interest rate $2 \mathrm{nd} A \mathrm{AR}$ parameter } & $\phi_{2 i}$ & $\begin{array}{l}-0.9462 \\
(0.0363)\end{array}$ \\
\hline & US dollar index & \\
\hline S.D. of permanent shocks to US dollar index & $\sigma_{\eta d}$ & $\begin{array}{c}0.0148 \\
(0.0029)\end{array}$ \\
\hline S.D. of temporary shocks to US dollar index & $\sigma_{\varepsilon d}$ & $\begin{array}{l}0.0158 \\
(0.0027)\end{array}$ \\
\hline US dollar index drift & $\mu_{d}$ & $\begin{array}{l}-0.0026 \\
(0.0021)\end{array}$ \\
\hline US dollar index 1st AR parameter & $\phi_{1 d}$ & $\begin{array}{l}1.3585 \\
(0.1144)\end{array}$ \\
\hline \multirow[t]{2}{*}{ US dollar index 2nd AR parameter } & $\phi_{2 d}$ & $\begin{array}{l}-0.5726 \\
(0.0980)\end{array}$ \\
\hline & Cross-series correlations & \\
\hline $\begin{array}{l}\text { Correlation: Permanent dollar credit/ } \\
\text { Permanent interest rate }\end{array}$ & $\rho_{\eta y \eta i}$ & $\begin{array}{c}0.6669 \\
(0.2118)\end{array}$ \\
\hline $\begin{array}{l}\text { Correlation: Permanent dollar credit/ } \\
\text { Permanent dollar index }\end{array}$ & $\rho_{\eta y \eta d}$ & $\begin{array}{c}0.0842 \\
(0.3396)\end{array}$ \\
\hline $\begin{array}{l}\text { Correlation: Permanent interest rate/ } \\
\text { Permanent dollar index }\end{array}$ & $\rho_{\eta i \eta d}$ & $\begin{array}{l}-0.6864 \\
(0.2532)\end{array}$ \\
\hline $\begin{array}{l}\text { Correlation: Transitory dollar credit/ } \\
\text { Transitory interest rate }\end{array}$ & $\rho_{\varepsilon y \varepsilon i}$ & $\begin{array}{l}-0.9719 \\
(0.1157)\end{array}$ \\
\hline $\begin{array}{l}\text { Correlation: Transitory dollar credit/ } \\
\text { Transitory dollar index }\end{array}$ & $\rho_{\varepsilon y \varepsilon d}$ & $\begin{array}{l}-0.9406 \\
(0.2205)\end{array}$ \\
\hline $\begin{array}{l}\text { Correlation: Transitory interest rate/ } \\
\text { Transitory dollar index }\end{array}$ & $\rho_{\varepsilon i \varepsilon d}$ & $\begin{array}{l}0.9941 \\
(0.0372)\end{array}$ \\
\hline
\end{tabular}


Figure 1: Trends from the Correlated Multivariate Unobserved Component Model

The figures below report the trend components of EME dollar credit, shadow interest rate and dollar index. The dollar credit in the EMEs is measured in log trillions of USD and multiplied by 100 . The shadow interest rate is measured in percentage points. The log of US dollar index has been multiplied by 100 .

\section{Trend: EME Dollar Credit}

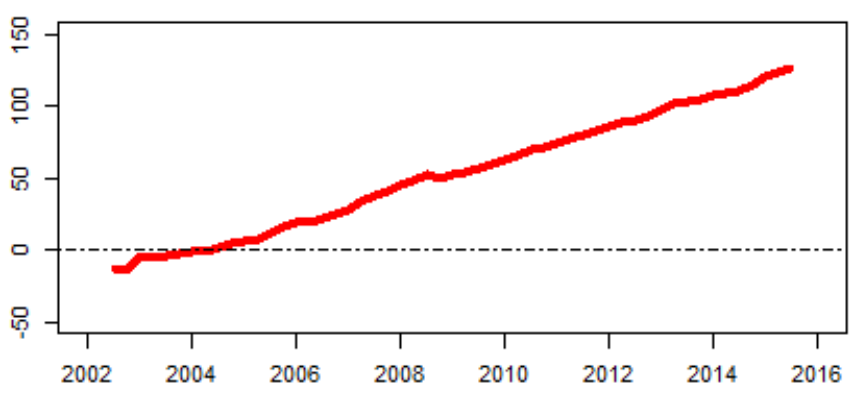

Trend: Monetary Policy Rate

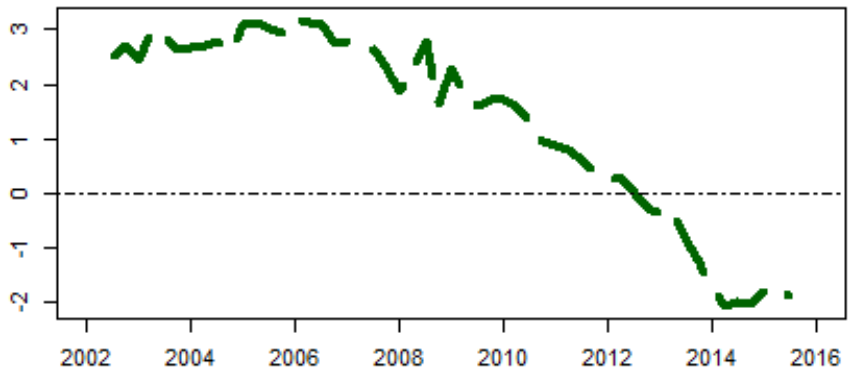

Trend: Dollar Index

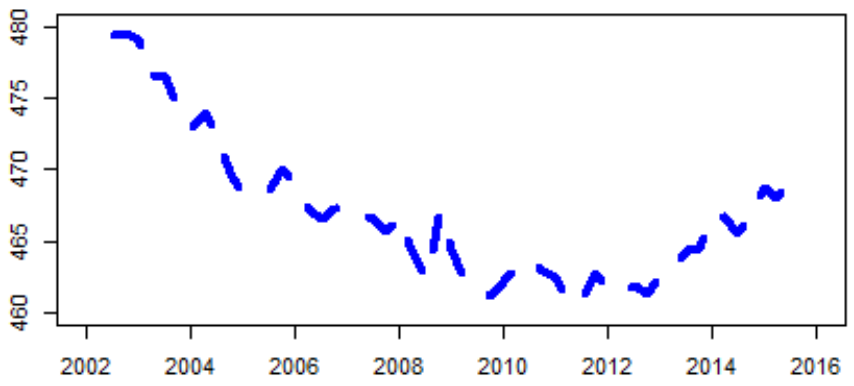


information about higher than expected inflation, which in turn may lead to a depreciation of the dollar as argued before. This will be associated with an unexpected permanent increase in dollar credit in emerging market economies. Overall, the results from the correlation analysis clearly suggests value in examining the short-run and the long-run relationships separately. The results suggest that fundamentals seem to matter more in the long-run, whereas the short-run boom may be associated with temporary phases of monetary policy as well as movements in dollar index.

\section{$4.2 \quad$ Trend-Cycle Decomposition}

In this subsection, we decompose the trend and cycle of EME dollar credit, interest rate and dollar index using the correlated multivariate unobserved component model. The stochastic trend in the multivariate UC model captures the long-run evolution in EME dollar credit and also reflects the effect of recent global financial crisis (Figure 2). In the long-run, there is an increasing trend in EME dollar credit, due to the global financial integration. There was a downward shift in the trend during the financial crisis. The effect of this negative shock on the trend of EME dollar credit persisted for few years.

The cyclical component from our multivariate UC model captures the evolution of the dollar credit and its dynamic relationship with US interest rate and the dollar index really well (Figure 2). During the initial part of our sample, the dollar credit cycle was negative implying lower than potential credit in these countries. After the collapse of Bear Stearns, emerging market economies provided a sanctuary for the international capital, mainly because the investor community assumed that the EMEs are decoupled from the developed markets.In the third quarter of 2008, Lehman Brother filed bankruptcy that led to financial panic. These events were associated with a global contraction in credit lending, which brought the dollar credit back down to its long-term trend. During this time period, the Federal Reserve lowered the policy rate significantly and dumped liquidity into the financial market through several runs of the QE programs. The portfolio re-balancing effect quickly directed the investors to the credit market in the EMEs to 
Figure 2: Trend and Cycle Decomposition from Correlated Multivariate UC Model

This figure reports the trend component and the cyclical component of EME dollar credit. The dollar credit in the EMEs is measured in log trillions of USD and multiplied by 100 . The UC trend is the trend component of EME dollar credit decomposed using the correlated multivariate unobserved component (UC) model. The HP trend is the trend component of EME dollar credit decomposed using Hodrick and Prescott (HP) filter.
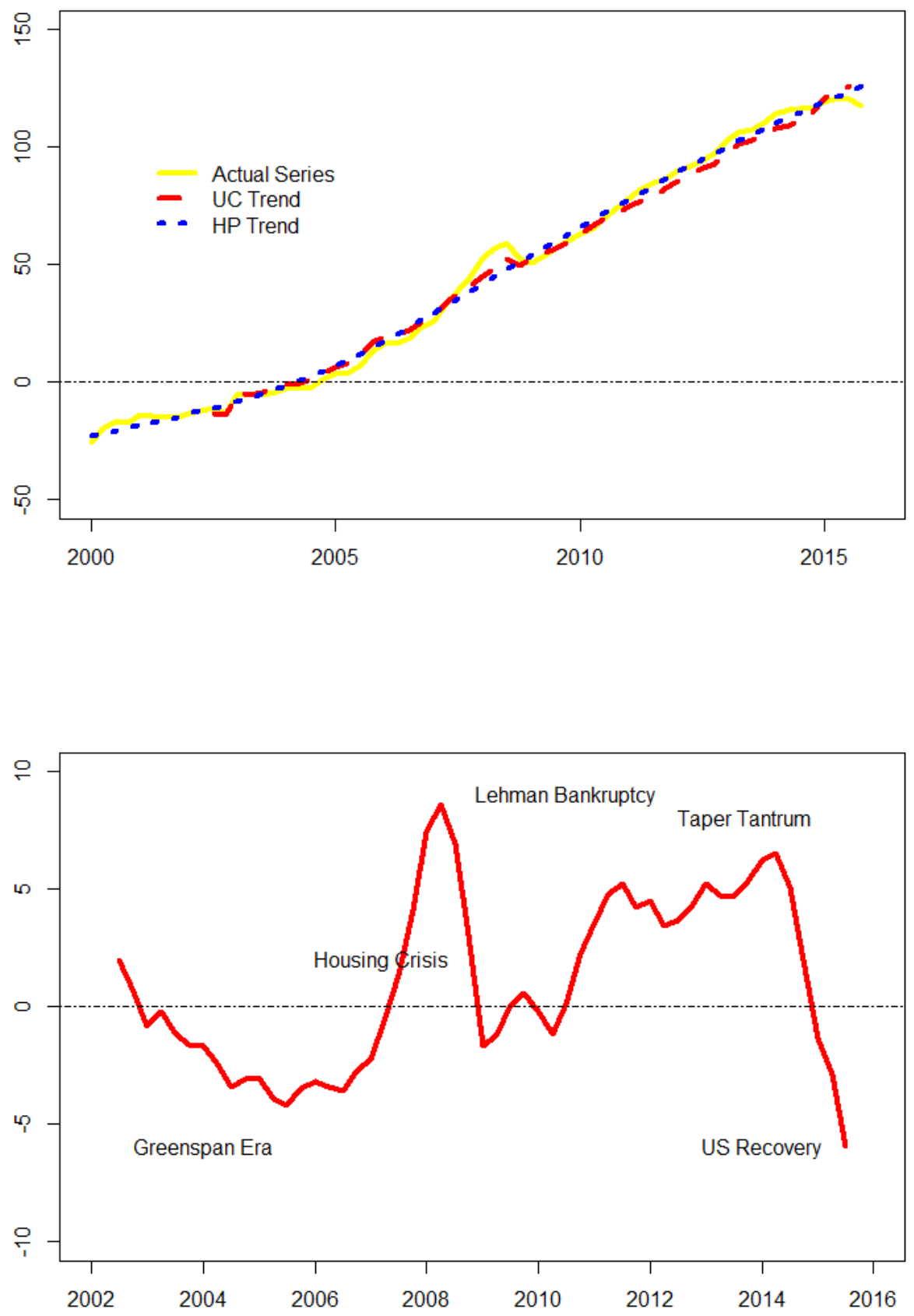
chase for yield. Shin (2013) denotes the year 2009 as the beginning of the second phase of global liquidity, because of the rapid capital flow into the EMEs in the form of nonfinancial firm bond issuance. Our cyclical component from the multivariate UC model indicates the expansionary cycle of EME dollar credit during 2009-2014, a phenomenon widely observed and agreed upon among the financial market observers and researchers. Starting from 2015, the persistent recovery of US economy and the slowdown in the EMEs overturned the dollar credit flow and created the concern about the instability of the EME financial markets and the feedback loops between the EMEs and advanced economies.

Figure 3: Cycles in the Correlated Multivariate Unobserved Component Model

This figure reports the cyclical components of the three variables EME dollar credit, shadow interest rate and the dollar index. The dollar credit in the EMEs is measured in log trillions of USD and multiplied by 100. The shadow interest rate is measured in percentage points. The US dollar index is in logs and has been multiplied by 100 .

Cycle: EME Dollar Credit

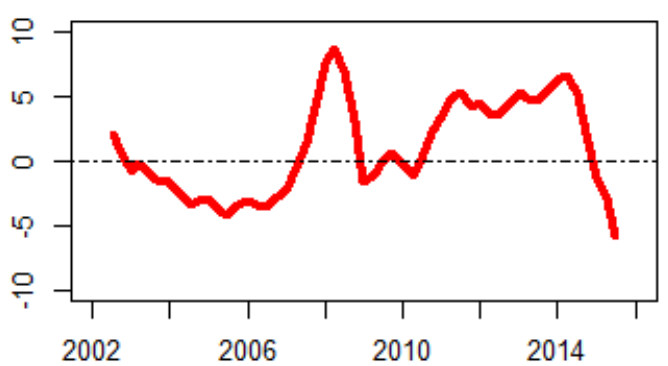

Cycle: Dollar Index

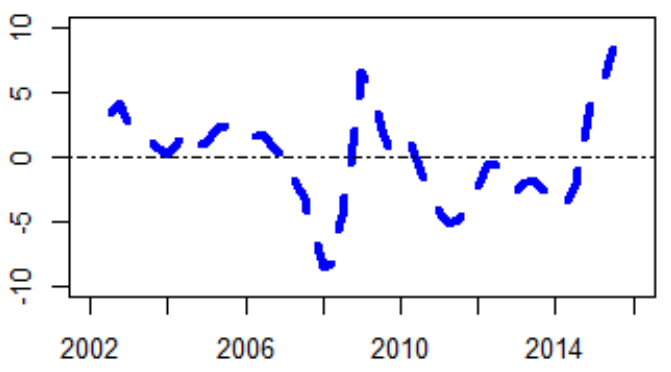

Cycle: Monetary Policy Rate

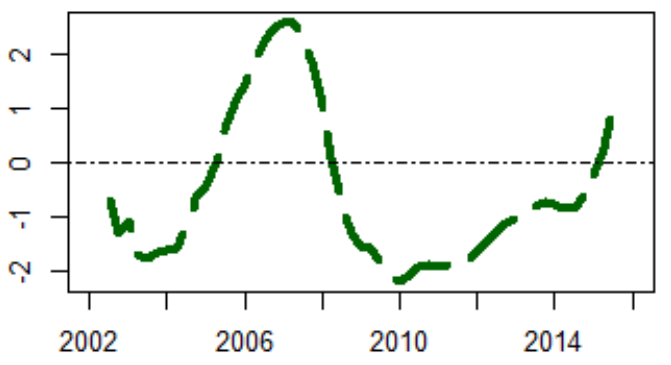

Cycle: EME Dollar Credit / Dollar Index

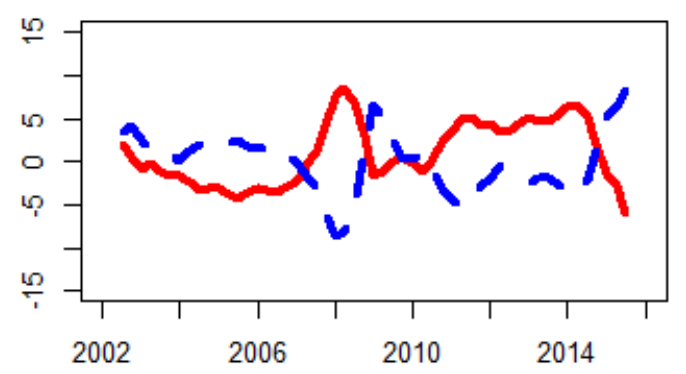




\subsection{Comovement among the Cyclical Components}

The estimated cyclical components from our model are displayed in Figure 3. Both the qualitative and quantitative measures of the cycles are consistent with intuition and they follow the dynamics of dollar credit, interest rates and dollar index very well. We observe that cyclical variation in dollar index is strongly negatively associated with the cyclical variation of EME dollar credit. Before 2008 financial crisis, when dollar was relatively strong, the overall EME dollar credit was increasing but was still below its trend, consistent with the idea that stronger dollar works against capital inflow in the EMEs. The correlation between the cyclical components of EME dollar credit and the dollar index suggests that the weak dollar could potentially contribute to the surge in the credit flow into the EMEs. When the financial crisis hit the US economy, the dollar depreciated and the investors with dollar assets were looking for higher yields in alternative asset classes. During this recessionary phase in the US, EME dollar credit witnessed an expansionary period during the 2009-2014 sample period. The negative correlation between cyclical components of EME dollar credit and the dollar index also suggests that the strong dollar could potentially slow down the credit flow into the EMEs. Since 2015, the recovery of the US economy has played a role in strengthening of the US dollar and as a result financial markets started anticipating a hike in the interest rates. EME dollar credit seemed to have entered a contractionary phase during this time period. Note that the overall EME dollar credit could still increase due to the underlying increasing trend. The dollar index is also relevant for the market participants to estimate the overall return when US policy rate hits the zero-lower bound. The risk of international carry trade, a typical cyclical investment behavior, mainly comes from the exchange rate risk under this environment. Therefore, it is not surprising that the dollar index can provide useful information in understanding the EME dollar credit conditions.

The plot of the cyclical component of interest rate suggests that interest rates were slightly above its long-run trend prior to the great recession. In the earlier part of the sample, the results suggest that the interest rate were below its trend suggesting an accommodative stance of monetary policy. This is consistent with the arguments 
proposed in the literature that has argued that the interest rates were too low in the prefinancial crisis period (Taylor, 2007). The unconventional monetary policy tools utilized by the Federal Reserve during the great recession led to a decline in the interest rate below its long-run average in our model during and after the great recession. This period was also associated with surge in dollar credit above its long-run trend as shown in Figure 3. The plot also shows that interest rate started moving towards its long-run trend at the beginning of 2015 and this is also associated with the decline in the cyclical component of dollar credit.

\section{Robustness Check}

In this section, we check the robustness of our results by substituting $\mathrm{Wu}$ and Xia (2016) shadow interest rate with other proxies for the stance of monetary policy. We also compare the estimated trend-cycle from our approach with univariate trend-cycle decomposition using different methods.

\subsection{An Alternate Measure of Interest Rate}

As explained earlier, there are several possible proxies that can capture the stance of monetary policy. We use shadow interest rate because it does not suffer from ZLB problem, and is also not contaminated by term premium . The shorter term interest rates, for instance, federal funds rate or three-month treasury bill rate, suffer seriously from the ZLB issue during post-2008 sample period. While the longer term interest rates raise less concern from this problem, they are more easy to be contaminated by the variation in the term premium. Since our EME dollar credit measure aggregates all the credit instruments, regardless of the term to maturity, by taking the middle ground, we use one-year Treasury bill rate in the model to check the robustness of our result. The results from this exercise is shown in Figure 4. The plot clearly shows the robustness of our estimation to the use of 1-year interest rate as a measure of monetary policy stance, as the estimated cycle closely resembles the one with the shadow rate as a measure of 
monetary policy stance.

Figure 4: The Cyclical Component from Correlated Multivariate UC Model

This figure reports the cyclical component of EME dollar credit. The dollar credit in the EMEs is measured in log trillions of USD and multiplied by 100. The UC cycle (Shadow Rate) is the cyclical component of EME dollar credit decomposed using the shadow interest rate as the measure of US monetary policy stance in the correlated multivariate unobserved component (UC) model. The UC cycle (1-year T-bill Rate) is the cyclical component of EME dollar credit decomposed using the one-year treasury bill rate as the measure of US monetary policy stance in the same UC model setup.

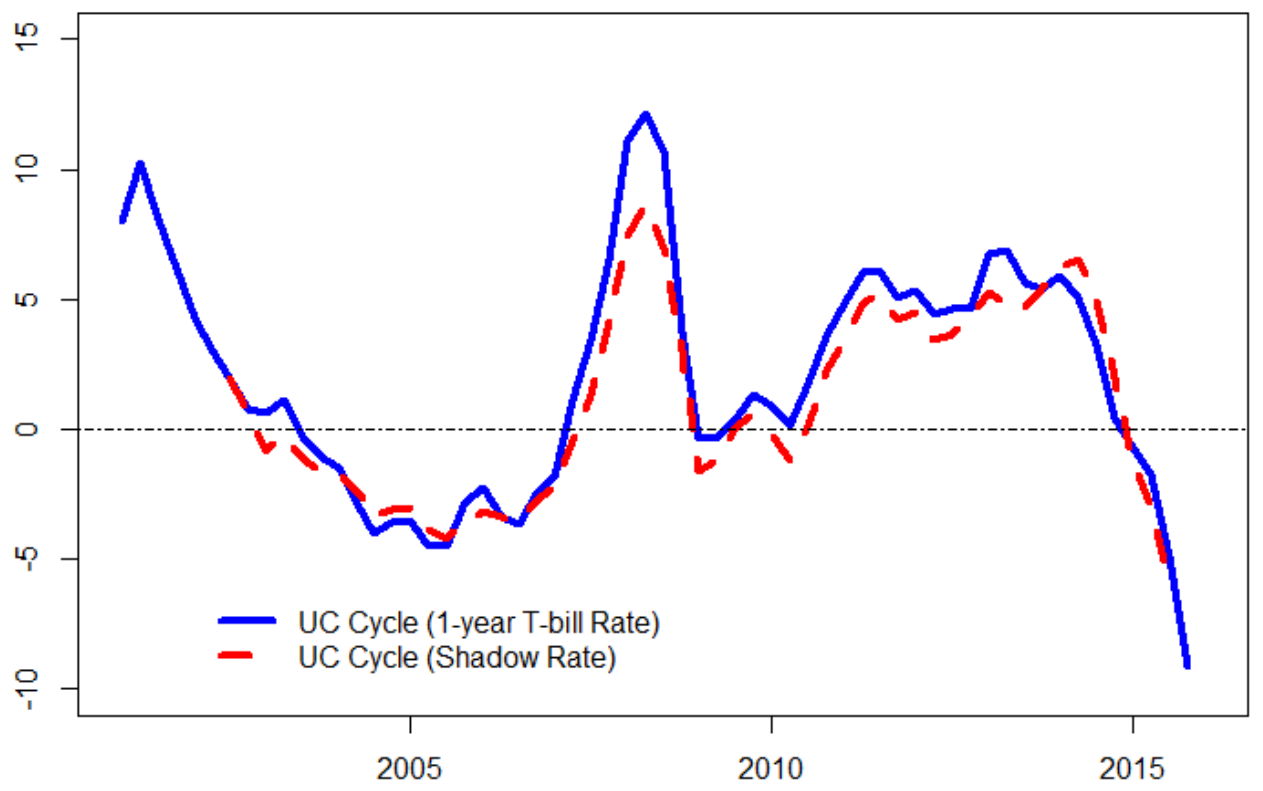

\subsection{Comparison with Univariate Trend-Cycle Decomposition}

\section{Models}

In addition to the estimation of the correlation between shocks to the permanent and transitory component, the use of multivariate model in theory should also provide us a superior measure of trend and cycle as compared to the univariate model. To examine this hypothesis, we also perform trend-cycle decomposition using the univariate models (Figure 5). The univariate models include a linear trend model, a HP filter model and a univariate UC model. The linear trend model decomposes the EME dollar credit series into a linear-trend component and a cycle component. The HP filter method uses an 
algorithm to smooth the original data series to estimate the trend component and the difference between them is the cyclical component. The parameter value $\lambda$ is set at 1600 as suggested by Hodrick and Prescott for the quarterly data. The univariate UC model only uses the series of EME dollar credit to decompose a stochastic trend component and a cyclical component with the same specification as in the multivariate UC model.

Figure 5: Comparing EME Dollar Credit Cycles

This figure reports cyclical components of EME dollar credit based on alternate decompositions.

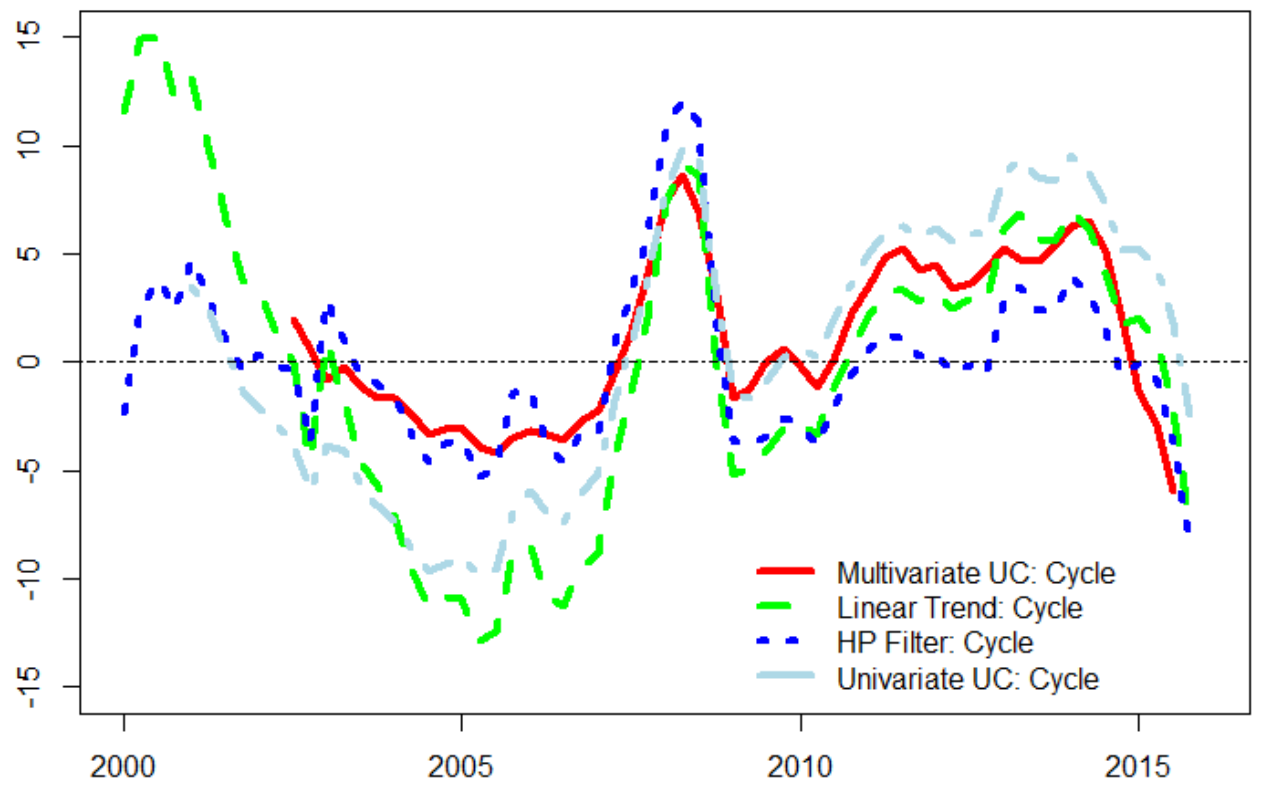

The results presented above clearly demonstrates that the estimate of trend and cycles obtained from the the multivariate UC model is better able to capture the dynamics of these three variables. The linear trend model, assuming a constant slope in the trend component, is not appropriate since it assumes no shock to the trend. The recent crisis is considered as the most severe financial crisis after the Great Depression (1929-1933) and we observe a clearly big negative shock to EME dollar credit series which the linear trend model is unable to capture. Other univariate models, without assuming a linear trend, fail to generate realistic trend and cycle series by ignoring the relationship between EME dollar credit and its price channels. The HP cycle seems to mimic the counterpart from 
multivariate UC model very well before the crisis but diverge afterwards. The cycle from the univariate UC model, instead, is close to the multivariate counterpart after the crisis. Taking into account all the historical events as mentioned in the cycle interpretation, the outflow of dollar credit slowed down before the crisis, due to the domestic boom, but the magnitude of the negative cycle did not seem to be as large as suggested by the univariate UC model. The HP cycle fails to capture the credit boom since 2009, while it performed reasonably well before the crisis. Overall, it is clear from the analysis presented above that there is valuable pay-off in utilizing information from other variables that are useful in explaining EME dollar credit if one is interested in extracting its permanent and transitory component.

\section{The Effects of US Monetary Policy Shock}

With global financial integration and dollar as international currency, US monetary policy plays a critical role in global liquidity transmission. Both the Fed and the EME authorities are concerned about the dynamic impact of US monetary policy changes on the international financial system. It would be an interesting exercise, therefore, to examine the dynamic impact of monetary policy shock on dollar credit in the EMEs using our multivariate unobserved component model.

Figure 6 plots the impulse responses of EME dollar credit and US dollar index when there is a transitory Fed interest rate hike. Based on our model, the cyclical variation of the three variables are correlated through the contemporary shocks in the error terms. Given a positive transitory shock to US monetary policy, we would expect a negative contemporaneous transitory shock to EME dollar credit and a positive contemporaneous transitory shock to dollar index. The effects of the transitory shock would not disappear immediately after the current period because of the persistent nature of the cyclical components as it depends on the lagged values. From our impulse response analysis, we find a hump shaped response of US dollar index and a U-shaped response of dollar credit to a contractionary monetary policy shock. The transitory nature of the shock 
Figure 6: Impact of a Transitory Increase in Interest Rate

This figure reports the impulse response functions of EME dollar credit and the dollar index to to a temporary increase in US interest rates

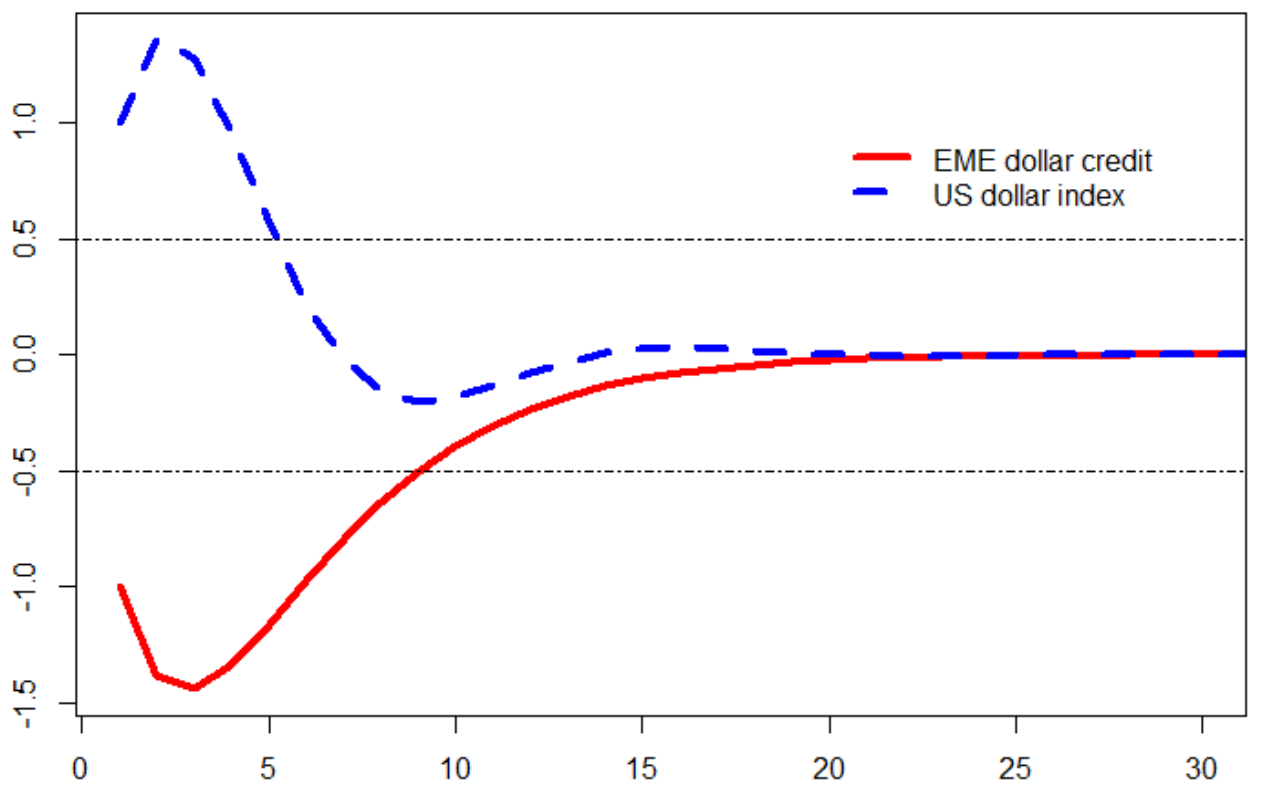

suggests that these effects slowly disappear over time. The results suggest that the US dollar index and EME dollar credit do not move to the new equilibrium immediately after the transitory shock to US monetary policy. From policy maker perspective, the US interest rate hike above it long-run trend would strengthen US dollar and induce dollar credit outflow for several months. Although the effect eventually disappears, however, the transition process may come with international financial instability. On one hand, the process creates the challenges in the balance of payment for the EME authorities. They need to equip with enough official reserves to manage the rapid outflow of capital and stabilize the foreign exchange rate. On the other hand, the appreciation of US dollar and the outflow of dollar credit leave the EME borrowers pressured to pay back the dollar-denominated debt.

In order to be prepared for the transmission of international financial risk, in this case through the rise in US interest rate above its trend, policy makers should adopt both 
macro- and micro-prudential policies to deal with the monetary policy spillover effect. Traditional macro-prudential policies focus on the soundness of financial corporations, however, after 2009, non-financial firms engage heavily in the carry trade activities and serve as surrogate financial intermediaries. The associated financial risks create new challenges to the existing regulatory framework. For example, Hoffman (2014) provides evidence that the very low world funding interest rates are associated with a rise in volatile capital flows and asset market bubbles in fast-growing emerging markets. Furthermore, although the integration of financial markets promote risk sharing in the long run, in the short run, the external liquidity shocks and the interconnectivity of financial markets make the international financial risk transmission easier and faster. In other words, the global financial system may become more fragile in the short run, due to the externalities in the market. ${ }^{15}$ Internalizing the costs and benefits require macro-prudential policy and international coordination.

\section{Conclusion}

In this paper, we use a correlated multivariate unobserved component model to examine the hypothesis about the role of ultra low US interest rates in the dollar credit boom in the emerging market economies. In doing so, we also decompose the movements in dollar credit in emerging markets, US interest rate and the dollar index into a permanent and transitory component. The correlations among the cyclical components support the idea that the rise of dollar credit in the EMEs is associated with US interest rate and the US dollar index below its long-run trend. The estimated permanent and transitory component from our model captures the dynamic features of EME dollar credit series and performs better than univariate benchmarks in capturing the boom and the boost during the last few years. The strong cyclical correlations among dollar credit in the EMEs, US interest rate and the dollar index suggest that the policymakers may need to take into account the US monetary policy spillover effect on domestic credit conditions of the EMEs,

\footnotetext{
${ }^{15}$ Leijonhufvud (2007) suggests that the structural features inherent in today's financial markets that directly contribute to the instability in EM capital flows.
} 
by observing the stance of the US monetary policy and the behavior of the US dollar in the foreign exchange market. Macro-prudential policies and international coordination may be justified and needed, along with micro-prudential policies, as a consequence of global liquidity transmission and the implied international financial instability.

\section{References}

[1] Avdjiev, S., McCauley, R., \& McGuire, P. (2012). Rapid credit growth and international credit: Challenges for Asia (No. 377). Bank for International Settlements.

[2] Bhatt, V., \& Kishor, N. K. (2015). Are all movements in food and energy prices transitory? Evidence from India. Journal of Policy Modeling, 37(1), 92-106.

[3] Black, F. (1995). Interest Rates as Options. The Journal of Finance, 50(5), 13711376.

[4] Borio, C. E., McCauley, R. N., \& McGuire, P. (2011). Global credit and domestic credit booms. BIS Quarterly Review, September.

[5] Bruno, V., \& Shin, H. S. (2016). Global dollar credit and carry trades: a firm-level analysis. Available at SSRN 2614074.

[6] Caballero, J., Panizza, U., \& Powell, A. (2015). The second wave of global liquidity: Why are firms acting like financial intermediaries? (No. 10926). CEPR Discussion Papers.

[7] Chung, K., Lee, J. E., Loukoianova, E., Park, H., \& Shin, H. S. (2015). Global liquidity through the lens of monetary aggregates. Economic Policy,30(82), 231-290.

[8] Farhi, E., Caballero, R., \& Gourinchas, P. O. (2008). An Equilibrium Model of Global Imbalances and Low Interest Rates. American Economic Review,98(1).

[9] He, D.,\& McCauley, R. N. (2013). Transmitting Global Liquidity to East Asia: Policy Rates, Bond Yields, Currencies and Dollar Credit (No. 152013). 
[10] Hoffmann, A. (2014). Zero Interest Rate Policy and Unintended Consequences in Emerging Markets. The World Economy, 37(10), 1367-1387.

[11] Kim, C. J., \& Nelson, C. R. (1999). State-space models with regime switching: classical and Gibbs-sampling approaches with applications (Vol. 2). Cambridge, MA: MIT press.

[12] Landau, J. P. (2011). Global liquidity-concept, measurement and policy implications. CGFS Papers, 45.

[13] Leijonhufvud, C. (2007). Financial Globalisation and Emerging Markets Volatility. The World Economy, 30(12), 1817-1842.

[14] Lombardi, M., \& Zhu, F. (2014). A shadow policy rate to calibrate US monetary policy at the zero lower bound (No. 452). Bank for International Settlements.

[15] McCauley, R. N., McGuire, P., \& Sushko, V. (2015). Dollar credit to emerging market economies. BIS Quarterly Review December.

[16] McCauley, R. N., McGuire, P., \& Sushko, V. (2015). Global dollar credit: links to US monetary policy and leverage. Economic Policy, 30(82), 187-229.

[17] McKinnon, R. (2010). Rehabilitating the unloved dollar standard. Asian-Pacific Economic Literature, 24(2), 1-18.

[18] McKinnon, R., \& Schnabl, G. (2012). China and Its Dollar Exchange Rate: A Worldwide Stabilising Influence? 1. The World Economy, 35(6), 667-693.

[19] McKinnon, R. I. (2013). The Unloved Dollar Standard: From Bretton Woods to the Rise of China. Oxford University Press.

[20] Morley, J. C. (2007). The slow adjustment of aggregate consumption to permanent income. Journal of Money, Credit and Banking, 39(2-3), 615-638.

[21] Morley, J. C., Nelson, C. R., \& Zivot, E. (2003). Why are the Beveridge-Nelson and unobserved-components decompositions of GDP so different?.Review of Economics and Statistics, 85(2), 235-243. 
[22] Obstfeld, M. (2010). The immoderate world economy. Journal of international money and finance, 29(4), 603-614.

[23] Santos, T. (2015). Credit booms: implications for the public and the private sector (No. 481). Bank for International Settlements.

[24] Shin, H. S. (2014). The second phase of global liquidity and its impact on emerging economies. In Volatile Capital Flows in Korea (pp. 247-257). Palgrave Macmillan US.

[25] Sinclair, T. M. (2009). The relationships between permanent and transitory movements in US output and the unemployment rate. Journal of Money, Credit and Banking, 41(23), 529-542.

[26] Taylor, J. (2007), "Housing and Monetary Policy," Working Paper, Stanford University.

[27] Wu, J. C.,\& Xia, F. D. (2016). Measuring the macroeconomic impact of monetary policy at the zero lower bound. Journal of Money, Credit and Banking, 48(2-3), 253-291. 